\title{
ANTI-BIOFILM AND ANTI-QUORUM SENSING PROPERTIES OF ETHANOL AND AQUEOUS EXTRACTS OF ORTHOSIPHON STAMINEUS AND ANDROGRAPHIS PANICULATA LEAVES AND STEMS
}

Farah Adiba bt Yang Abd Talib ${ }^{1}$, Hairul Aini Hamzah ${ }^{1}$ and Mohammed Imad Al-Deen Mustafa Mahmoud ${ }^{1}$

${ }^{1}$ Department of Basic Medical Sciences, Kuliyyah of Medicine, International Islamic University Malaysia

Presenter: Farah Adiba, orphnoch89@yahoo.com

Introduction: Quorum sensing controls a wide spectrum of processes and phenotypic behaviours including biofilm formation that helps in the survival and virulence of bacteria in hosts. Thus, anti-quorum sensing is suggested to combat bacterial infections. This study aimed to evaluate the anti-biofilm forming and anti-quorum sensing activities which may contribute to the anti-bacterial effect of ethanol and aqueous extracts of Orthosiphon stamineus and Andrographis paniculata leaves and stems.

Materials and method: General biofilm assay protocol with modification was used for the biofilm assay to test the effect of different concentration $(2 \mathrm{mg} / \mathrm{ml}$ and $3 \mathrm{mg} / \mathrm{ml})$ of extracts on the biofilm formation by Pseudomonas aeruginosa. Optical density of crystal violet/acetic acid solution was measured at $595 \mathrm{~nm}$ and the percentage of biofilm inhibition was calculated. In quorum quenching assay, visualization of reporter strain Al1-QQ.1 growth will be used for the detection of bio-molecules interfering with acyl homoserine lactone $(\mathrm{AHL})$.

Results: Extracts with the highest ability to inhibit biofilm formation were ethanol extract of O.stamineus stem and A.paniculata leaves with $77.84 \%$ at extracts concentration of $3 \mathrm{mg} / \mathrm{ml}$. Aqueous extract of O.stamineus leaves showed the least potential with $13.41 \%$ inhibition. However, aqueous extract of A.paniculata showed zero inhibition at $3 \mathrm{mg} / \mathrm{ml}$ and two extracts (aqueous extract of 0. stamineus and A.paniculata leaves) gave negative value at concentration of $3 \mathrm{mg} / \mathrm{ml}$ and $2 \mathrm{mg} / \mathrm{ml}$, respectively. Quorum quenching assay has yet to be done.

Conclusion: It could be concluded that most of the extracts possess anti-biofilm property. 